\title{
Intestinal microbiota, probiotics and mental health: from Metchnikoff to modern advances: Part II - contemporary contextual research
}

\author{
Alison C Bested ${ }^{1}$, Alan C Logan ${ }^{2^{*}}$ and Eva M Selhub ${ }^{3}$
}

\begin{abstract}
In recent years there has been a renewed interest concerning the ways in which the gastrointestinal tract - its functional integrity and microbial residents - might influence human mood (e.g. depression) and behavioral disorders. Once a hotbed of scientific interest in the early 20th century, this area lay dormant for decades, in part due to its association with the controversial term 'autointoxication'. Here we review contemporary findings related to intestinal permeability, small intestinal bacterial overgrowth, lipopolysaccharide endotoxin (LPS) exposure, D-lactic acid, propionic acid, and discuss their relevance to microbiota and mental health. In addition, we include the context of modern dietary habits as they relate to depression, anxiety and their potential interaction with intestinal microbiota.
\end{abstract}

Keywords: Intestinal microbiota, Autointoxication, Depression, Anxiety, Probiotics, Microbial ecology, Lipopolysaccharide endotoxin, Diet, Intestinal permeability, Microbial ecosystems

\section{Introduction}

As outlined in Part I of this review, early 20th century scientists and clinicians placed emphasis on the importance of the gastrointestinal tract - its functional integrity and its microbes - as an influencing factor in depression and other mental health disorders. The interest in this topic, housed under the controversial term of autointoxication, disappeared rapidly by 1930 . The reverse-order, top-down, focus would subsequently dominate research for decades; i.e. depression and anxiety as an influencing factor in the gastrointestinal disorders. We introduce Part II by reflecting upon one of the last articles of the autointoxication genera (1933), wherein neuropathologist Armando Ferraro and clinical psychiatrist Joseph E. Kilman of the New York Psychiatric Institute wrote the following in Psychiatric Quarterly journal [1]:

'It is far from our mind to conceive that all mental conditions have the same etiological factor, but we feel justified in recognizing the existence of cases of mental

\footnotetext{
* Correspondence: aclnd@cfs-fm.org

${ }^{2}$ CAMNR, 775 Blithedale Avenue, Suite 364, Mill Valley, CA 94941, USA

Full list of author information is available at the end of the article
}

disorders which have as a basic etiological factor a toxic condition arising in the gastrointestinal tract'

In 1933, with the understanding that 'we must not forget here the possibility that in the future more appropriate and more delicate biochemical methods may allow us to detect [circulating gut-derived toxins] in an easier and more accurate way than we are now able to do, Ferraro and Kilman proposed a multi-discipline collaborate effort. They wanted to establish a framework and begin with careful experimental lines of investigation. Their recommendation was to bring together experts to examine the following variables, while at the same time taking into consideration observable changes in animal behavior.

1. Alterations in intestinal permeability to toxins

2. The effect of synergy among potentially toxic chemicals arising from the gastrointestinal tract (e.g. others had only examined indole and p-cresol individually; in preliminary experiments, Ferraro and Kilman reported that gut-derived toxins produced CNS toxicity at much lower doses vs. solo administration). 
3. Alterations to the intestinal microflora and factors of bacteriology

4. Alterations in liver and/or kidney function

5. Alterations to dietary patterns

Knowing that each of these variables could interact with one another, Ferraro and Kilman concluded 'All these problems will require time and we hope to be in a position to report on them some time in the future'. Their paper and plans, however, lay dormant and virtually unreferenced. History would show that their research 'wish-list' would remain unfulfilled for 70 years. Here, in Part II, we will examine many lines of contemporary research and integrate what is now known concerning portions of Ferraro and Kilman's framework. Threads from various branches of medicine, with the aid of advanced scientific technique, provide a mosaic of context that cannot be overlooked in future gut-brain-microbiota research. As we will discuss, the conundrum of interaction between the above variables continues to hamper the clinical relevance of experimental probiotic science in the brain and behavioral context.

\section{Part II - Modern studies of relevance to Gut-brain- microbiota connection}

Within our original hypotheses on the potential value of probiotics for states of fatigue and depression $[2,3]$, we sewed together separate lines of emerging research from multiple branches of medicine. The potential mechanistic pathways we proposed are highlighted in Table 1. Most

Table 1 Probiotics for fatigue and depression - proposed pathways - adapted from Medical Hypotheses - Logan, et al. [2] and Logan, et al. [3]

\footnotetext{
- Direct protection of the intestinal barrier

- Influence on local and systemic antioxidant status, reduction in lipid peroxidation

- Direct, microbial-produced neurochemical production - e.g. GABA

- Indirect influence on neurotransmitter/neuropeptide production

- Prevention of stress-induced alterations to overall intestinal microbiota

- Direct activation of neural pathways between gut and brain

- Limitation of inflammatory cytokine production

- Modulation of neurotrophic chemicals including brain-derived neurotrophic factor

- Limitation of carbohydrate malabsorption

- Improvement of nutritional status - e.g. omega-3 fatty acids, minerals, phytochemicals

- Limitation of small intestinal bacterial overgrowth

- Reduction of amine/uremic toxin burden

- Limitation of gastric/intestinal pathogens (e.g. Helicobacter pylori)

- Analgesic properties
}

noteworthy, perhaps, was the increasing recognition that mental health disorders are associated with low-grade inflammation (e.g. C-reactive protein), oxidative stress, and the elevation of inflammatory cytokines (e.g. TNF- $\alpha$, IL-1, IL-6). Indeed, mood disturbances and fatigue could be induced by the systemic administration of lipopolysaccharide endotoxin (LPS) [4]. At the same time, with the emergence of publications indicating that probiotics could influence systemic cytokines, oxidative stress, and inflammatory markers upon oral consumption [5], a moodregulating effect seemed scientifically plausible. There was also research around that time indicating that otherwise non-desirable gut microbes (e.g. Campylobacter jejuni), at quantities too low to produce a detectable immune response, could influence animal behavior indicative of human anxiety [6]. This suggested to us that probiotics, either directly, or through their influence on other gut microbes, may also play a role in precisely the opposite direction - benefits to cognition and behavior via gut-tobrain communication.

In the decade subsequent to the hypotheses, the expansion of direct and indirect probiotic-brain research has been immense. A number of groups, including our own, have published preliminary human studies showing that orally consumed probiotic strains can indeed influence aspects of mental outlook and cognition [7-9]. The human studies have also been supported by a variety of elegant bench/rodent studies that have helped to shed light on the potential pathways whereby probiotic microorganisms can influence brain and behavior [10]. Below are updated discussions concerning these pathways and the critical links between the gastrointestinal tract, its microbial residents, and mental health. Although the gutmicrobiota-brain connection may ultimately extend clinically to diverse conditions, from autism to schizophrenia $[11,12]$, for the purposes of this article, the focus will largely remain on advances in depression and anxiety.

\section{Inflammation, oxidative stress and endotoxins}

Within developed nations, up to one third of all visits to primary care clinicians involve patients with emotional disorders, most notably anxiety and/or depressive conditions [13]. As researchers explore the pathophysiology of mood and anxiety disorders, the links between elevations in markers of inflammation (e.g. cytokines, C-reactive protein) and emotional disorders have grown in strength [14]. Evidence also continues to indicate that the antioxidant defense system is overwhelmed in humans with major depressive disorder and that the burden of oxidative stress and inflammation becomes a viscous cycle [15]. Remarkably, even skin biopsy samples from depressed patients (vs. matched healthy controls) show higher levels of oxidative stress [16]. Moreover, researchers are beginning to understand how and why inflammation 
and oxidative stress can be both a cause and a consequence of depression [17]. Elevation in systemic inflammatory cytokines can signal the production of inflammatory cytokines within the central nervous system via microglia activation. Despite their critical role in neuronal repair, chronic activation of microglia can compromise neuronal functioning by setting in motion a cascade of inflammation and oxidative stress [18]. This, in turn, can compromise normal intra and extracellular neuronal communication.

Although a number of gut-derived bacterial products, Staphylococcal enterotoxin B as one example, can induce behavioral changes indicative of anxiety when administered in the periphery, a key component of the gut microbiota to brain connection are the increasingly robust studies involving the systemic administration of LPS endotoxins. LPS administration at low levels (e.g. $0.4 \mathrm{ng} / \mathrm{kg}$ ) has been shown to cause acute anxiety, depressive symptoms, cognitive deficits and increased visceral pain sensitivity [19-23]. The LPS is a structural portion of the external membrane of gram-negative bacteria, and it is estimated that humans harbor at least a gram of LPS in the intestinal lumen. In healthy adults there may be miniscule amounts of LPS found in blood plasma $(1-200 \mathrm{pg} / \mathrm{ml})$, indicating that the intestinal barrier performs its exclusionary role with good efficiency [24]. However, higher circulating LPS in the healthy general population and patient groups is positively associated with abdominal obesity, higher insulin, triglycerides, total cholesterol and other markers of cardiovascular and diabetes disease risk [25-27]. LPS is cleared from circulation by the liver and its enzyme alkaline phosphatase (AP) in particular [28]. LPS up-regulates AP activity and induces oxidative stress in the liver, therefore the ways in which antidepressant agents influence alkaline phosphatase and liver detoxification is under increased scrutiny [29].

Experimental investigations have made it clear that LPS-induced peripheral cytokine elevations can alter neuronal activity in the limbic system (e.g. increased amygdala activity) [30,31]. As well as causing excitotoxic neuronal overstimulation, the LPS-induced inflammation can increase the activity of indoleamine-2,3-dioxyegenase (IDO), an enzyme that breaks down tryptophan in the kynurenine pathway. IDO activity has been positively correlated with depressive symptoms, and kynurenine itself can increase anxiety when administered in the periphery. The end result of endotoxemia may be decreased tryptophan and enhanced kynurenine availability, along with compromised serotonergic functioning [32-34]. On the other hand, kynurenic acid, produced by commensal intestinal microbiota and found in traditional foods (honey, green vegetables, tubers), is readily absorbed from the GI tract $[35,36]$, and has been reported to have anxiolytic activity when administered in the periphery [37]. Systemic LPS can also induce brain or CNS cytokine production and alter behavior without the necessity of systemic cytokine involvement, with some research indicating a direct LPS to CNS communication via brain endothelial cells [38]. Indeed, systemic LPS can compromise the integrity of the normal blood-brain barrier (BBB) and facilitate the passage of a host of potential agents (environmental toxins, pathogens etc.) as well as LPS itself [39]. To make matters worse, the ability to remove potentially harmful neurotoxins (e.g. amyloid beta-derived neurotoxins) from the brain through normally functioning efflux mechanisms at the BBB is also compromised by LPS [40]. Among those with depression, the subsequent risk of dementia or mild cognitive impairment is up to 2-fold higher, and researchers continue to evaluate low-grade inflammation as a primary driver of cognitive decline [41]. Permeability of the blood-brain barrier and the intestinal barrier is, at least in part, controlled by endocannabinoid modulation. Endogenous cannabinoids are increased during inflammation (as are their receptors) in what appears to be an adaptive process - cannabinoid binding to receptors can attenuate LPS-induced blood-brain barrier permeability and intestinal inflammatory effects of LPS $[42,43]$. It is also worth noting that in animal studies, previous experience with physical and/or psychological stress (e.g. social defeat, tail shock) leads to an even more pronounced inflammatory cytokine release subsequent to LPS administration [44]. This suggests that in clinical populations certain individuals may be primed to experience a greater burden of inflammation and oxidative stress when specific agents (environmental toxins, bacterial products, etc.) find their way into systemic circulation.

\section{Intestinal permeability, bacterial overgrowth}

Of course, an obvious pathway to increased LPS exposure in the periphery would be a compromised intestinal barrier, and recent investigations have indeed shown signs of increased intestinal permeability in depression. In findings reminiscent of Johnson and Goodall's 1904 report on serum E. coli agglutination in depression [45], new studies report that patients with major depression (vs. healthy controls) have higher serum IgM and IgA against a variety of commensal gut bacteria [46-48]. Moreover, in conditions where depressive symptoms are often part of the picture - irritable bowel syndrome (IBS), myalgic encephalomyelitis (ME, aka chronic fatigue syndrome), fibromyalgia (FM), complex regional pain syndrome, alcohol dependency, insulin resistance, and obesity - studies involving human subjects have shown high rates of intestinal permeability [49-53]. Ferraro and Kilman were most intrigued why, in their experiments, certain animals of a given species were more resilient to the systemic consequences of 
intestinally-derived toxins than same-species counterparts [1]. Controlling for body weight, why didn't all animals react in similar fashion to equivalent systemic doses of gut-derived toxins? Seventy-seven years later, Italian researchers would show that abnormal intestinal permeability (IP) is a common finding in first-degree relatives of those with autism $(36.7 \%$ abnormal IP in those with autism, $21.2 \%$ in first-degree relatives, $4.8 \%$ in healthy controls) [54]. Backing up the claims of Fenton Turck over a century ago [55], psychological stress and splanchnic hypoperfusion subsequent to exhaustive exercise have recently been shown to increase intestinal permeability in adults [56,57]. Obviously the finding of increased intestinal permeability in over-lapping medical conditions provides clinical meaning to the LPS discussions above. In addition to LPS, a more porous intestinal barrier allows systemic access to food antigens (e.g. gliadin) environmental toxins (e.g. polychlorinated biphenyls etc.), exposure to which is a further risk factor for depressive symptoms $[58,59]$. Polychlorinated biphenyls can further compromise the integrity of the intestinal lining and cause deficits to the normal BBB permeability $[60,61]$. Meanwhile, probiotics have been shown to influence removal of environmental toxins from the gastrointestinal tract [62].

The early reports of low gastric acid among patients with melancholia, discussed in Part I, have been confirmed by more modern investigations involving patients with major depression $[63,64]$. The consequences of low stomach acid production include small intestinal bacterial overgrowth (SIBO) and further damage to the intestinal barrier. Use of gastric acid-blocking medications can provoke SIBO [65]. Clinically, SIBO sits on a wide continuum from asymptomatic to a severe malabsorption syndrome. For many, there may be very mild gastrointestinal symptoms, including bloating, diarrhea, abdominal pain, and constipation [66]. Once again, much like intestinal permeability, SIBO has been found in the aforementioned conditions - IBS, ME, FM, insulin resistance, and obesity [67-70]; it is strongly associated with depression and anxiety [71]. Interestingly, SIBO is found in erosive esophagitis [72], yet in the prospective treatment of gastro-esophageal reflux disease, those with depression and/or anxiety are the least likely to respond to proton pump inhibitors [73]. Given that SIBO and intestinal permeability have been linked together, an over-lap among these medical conditions should not be surprising. Remarkably, eradication of SIBO with antimicrobials improves emotional symptoms and restores the normal intestinal barrier [74]. SIBO can compromise proper absorption of proteins, fats, carbohydrates, B vitamins, and other micronutrients due to bacterial interference. Excess bacteria can successfully compete for nutrients, produce toxic metabolites, and cause direct injury to enterocytes in the small intestine $[75,76]$. All of this could, of course, influence mood indirectly. On the other hand, experimental studies show that psychological stress stagnates normal small intestinal transit time, encourages overgrowth of bacteria, and compromises the intestinal barrier [77]. In animal research, diarrhea and intestinal permeability are also reported together in the context of SIBO and stress [78]. The oral administration of probiotics has been shown to be beneficial in the reduction of SIBO [79]. Experimentally, an omega-3 deficient diet increases $\mathrm{SIBO}$, an interesting finding given the consistent relationship between inadequate omega-3 and depression [80].

\section{Intestinal microbiota, diet and modernization}

With an appreciation of inflammation, oxidative stress, LPS, intestinal permeability and SIBO as background, we can step back and examine the relevance of modern dietary patterns in the context of gut to brain health as mediated by microbes. Regarding the broad environmental influences on mental health, it has been shown in preliminary research that richness in species biodiversity (e.g. vegetation and birds) within urban environments is positively associated with mental well-being $[81,82]$. The same likely holds true regarding microbial biodiversity within the gut. For example, a loss of bacterial biodiversity is associated with GI disorders, skin conditions and obesity [83]. Remarkably, a recent study showed that diminished environmental biodiversity (measured as richness of a wide variety of plant species) in the proximity of personal residence is associated with lower genetic biodiversity of a bacterial species (gammaproteobacteria) on skin samples of those with atopy. This bacterial species and its upstream genus Acinetobacter have been specifically linked to anti-inflammatory cytokine production [84]. It is becoming increasingly clear that indigenous or traditional dietary patterns are inclusive of many bacterium species that might be considered to have probiotic potential. Consider that an estimated 35\% of all lactic acid bacteria isolated from raw fruits and vegetables can survive gastric conditions [85]. In the 1980s researchers made note of some significant differences in the fecal microflora of rural Japanese vs. Canadian urbanites. They found higher counts of bifidobacterium spp. and lactobacilli in the rural Japanese who maintained a traditional high-fiber diet rich in fermented foods, vegetables and fish. Using culture technique, Benno reported higher amounts of clostridia spp. in the Canadians, yet overall, there was greater biodiversity (more genera and species) in the rural-dwelling Japanese [86]. Following up, his team reported on the differences in fecal microflora among older adults residing in Tokyo vs. elderly rural Japanese maintaining a highfiber traditional diet. Once again, there were higher numbers of bifidobacterium spp. among the rural 
dwellers and lower amounts of clostridium spp, particularly C. perfringens [87].

More recent investigations have also shown marked differences in the fecal microbiota of western European children vs. rural African children living in an environment resembling that of Neolithic subsistence farmers. Using DNA sequencing of samples, researchers reported less potentially pathogenic bacteria, yet a far greater degree of biodiversity and microbial richness in rural Africans living a traditional lifestyle and consuming traditional high fiber foods [88]. A separate group of researchers has also noted distinct differences in the bacterial groups and their functional genes (those involving metabolism of amino acids, etc.) in US adults living in metropolitan centers vs. villagers living in Africa and South America. Once again, the fecal microbiota of US metropolitan adults showed far less diversity vs. villagers in these distinct regions. Diet was reported to be the control switch for intestinal microbiota, trumping other influences such as hygiene [89]. Beyond the 'hygeine hypothesis' (lack of exposure to diverse microbes increases risk of allergies and exaggerated immune response), researchers are questioning the broad implications of loss of microbial diversity as a consequence of modernization. DNA sequencing of stool samples in combination with detailed dietary analysis have allowed researchers to determine that long-term dietary patterns largely determine the main phyla of the gut microbial profile [90]. However, even short-term dietary changes can induce species-level changes to the intestinal microbial residents, as can psychological stress [91]. Although the administration of beneficial microbes may not have a major impact on stable phyla, probiotic intervention studies (as discussed later) serve to remind scientists that species-level application of microbes cannot be overlooked as clinically relevant. A single strain of lactobacillus can improve overall microbial diversity [83], while the administration of a single bifidobacterium strains can increase the quantity of separate bifidobacterium species and overall lactobacilli within the gut $[92,93]$.

To date, detailed analyses of the gut microbiota of patients with major depressive disorder have not been conducted by contemporary investigators. However, it is worth noting that alterations to 'normal' (i.e. modernized) human gut microbiota have been observed in the same group of aforementioned chronic conditions associated with a high degree of depressive symptoms - IBS, ME, obesity and type 2 diabetes [94-98]. A growing number of studies in both animals and humans are continuing to highlight the divergent effects of diet (fastfood style Western diet vs. traditional dietary patterns) on microbiota, LPS burden, and intestinal permeability [24]. Studies show that the high-energy (high-fat, lowfiber carbohydrates) diets typical of Western nations, can diminish levels of bifidobacteria, increase intestinal permeability and elevate blood LPS levels [99]. Human research shows that adherence to a typical Western-style diet (high fat and low-fiber carbohydrates) for one month can elevate plasma endotoxin activity by $71 \%$. By contrast, a switch to a low-fat, low saturated fat, fiberrich diet (so-called 'prudent' or more traditional diet) for one month can decrease baseline blood endotoxin activity by $38 \%$ in healthy adults [100]. A separate 24 -week study, in adults with clinical and laboratory signs of metabolic syndrome, showed that a low fat and high carbohydrate diet increased fecal bifidobacterium and reduced fasting glucose compared to baseline [101]. Animal studies indicate that when fat intake is very high (72\%) there is a 2.7 -fold increase in circulating LPS, while diets with $40 \%$ fat elevate circulating LPS by 1.4fold [102]. Recall that circulating LPS can interfere with $\mathrm{BBB}$ function, therefore it should not be surprising that high fat (40\% fat, mostly saturated fat from lard) diet disturbed cognitive performance and increased BBB permeability. Compared to the control standard chow group, the researchers discovered that the high-fat diet allowed a systemically administered dye, one normally excluded from the brain, into the hippocampus [103]. Separate groups of researchers have reported similar findings of a compromised BBB when animals are placed on Westernstyle diets [104].

The implications of this research to neuropsychiatric disorders are immense. With this as background, and given the focus on depression in the current paper, it is noteworthy that multiple epidemiological studies show that adherence to healthy dietary patterns, particularly the Mediterranean diet (similar to the prudent diet), is associated with lowered risk of depression and anxiety [105-108]. The reduction in risk of depression is clinically meaningful; consider that in 5-year prospective research, the resiliency factor of adherence to a Mediterranean and traditional dietary patterns is between $25-30 \%$ [107,108]. However, patients with depression and fatigue are typically far removed from traditional, prudent diets. Indeed, stress, depressive symptoms and high levels of anxiety are characteristically associated with increased frequency of fastfood choices and over-consumption of high-energy, low nutrient density foods [109-111]. Among the many implications of this dietary pattern in mental health, its ability to establish an 'inflammatory microbiome' is now worthy of further investigation.

To further illustrate the relevance of dietary choices in the entire gut-brain-microbiome spectrum, consider that more detailed analysis reveals that not all types of fats and/or simple carbohydrates influence these end-points (microbiota, intestinal permeability, LPS) by equal measure - for example, omega-3 oils, vs. oils rich in saturated fats, may have a positive influence on the intestinal 
barrier and limit the detrimental effects of LPS [112-114]. Conversely, the administration of bifidobacteria is associated with higher omega-3 levels in brain cells [115]. In other words, to what extent are the reported mental health benefits of omega- 3 fatty acids determined by resident intestinal microbiota? Among the simple sugars, fructose administration has been shown to increase circulating LPS by $40 \%$ (vs. controls, sucrose and glucose). In this dietary sugar research, the LPS was normalized after the administration of an antibiotic, indicating a direct microbial influence [116]. Given the massive rise in highfructose corn syrup (now representing $42 \%$ of all caloric sweeteners) [117], surely we must question its role in epidemiological studies linking overall simple sugar consumption to depression $[118,119]$. LPS and the microbiota could certainly be connected to the fairly robust relationship between fructose intolerance and depression $[120,121]$. Lowered blood tryptophan levels have been observed in fructose intolerance [122]; however, the new findings on LPS are a clear indication for further research.

The intestinal microbiota may also be involved in the potential value of dietary antioxidants to brain health. Fiber-rich carbohydrates, including whole fruits and vegetables, are abundant in a variety of antioxidant phytochemicals, most notably polyphenols. Researchers are currently examining the complementary ways in which antioxidant-rich foods and beverages influence gut microbiota and, in turn, how select constituents of gut microbiota influence phytochemical absorption [123-127]. For example, major dietary antioxidant sources such as cocoa, coffee, green tea, blueberries, and curcumin have all been linked in epidemiological studies to lowered risk of depression and/or cognitive decline [128-132]. Meanwhile, these dietary agents have been shown in human and animal studies to have beneficial effects on gut microbiota, including promoting the growth of lactobacilli and bifidobacteria [133-137]. Curcumin was recently shown to prevent LPS-induced intestinal permeability in an experimental model, while green tea reduces LPS-induced sickness behavior and BBB permeability [138-140]. Consider also the previously mentioned research on high-fat/highsugar (fructose) diets and elevated circulating LPS. In human research the consumption of orange juice along with a high-fat/high-carbohydrate (low fiber) meal prevented elevations in circulating endotoxin, elevations that were otherwise observed when the same meal is consumed with either pure water or glucose in water at the same concentration as found in orange juice [141]. Despite its fructose content, orange juice may negate the detrimental effects by virtue of its rich content of flavonoids.

Experimentally the links between these dietary influences on microbes (or microbes on the absorption of dietary components) and mood are evident; consider, for example, the observations that blueberry species, green tea, curcumin, pomegranate, and resveratrol polyphenolic extracts exert antidepressant activity and stress resiliency in animal models [142-146]. Research indicates that once absorbed, single phenolic structures can have subtle but meaningful effects on the breakdown of central neurotransmitters [146]. Emerging studies also allow for the suggestion that the behavioral benefits might be explained, at least in part, by their phytochemical influence on minimizing the effects of LPS and promoting lactobacilli and bifidobacteria growth at the expense of potentially pathogenic microbes. For example, long-term intake of honey, a feature of Paleolithic Age and traditional diets, has been shown in animal research to be associated with decreased anxiety and cognitive decline vs. sugar-free and sucrose controls [147]. It is worth noting that honey, in addition to its broad array of antioxidant phytochemicals, has been shown to negate the effects of LPS and increase the growth of lactobacilli and bifidobacterium $[148,149]$.

Lactic acid bacterium-inclusive (non-dairy) fermented foods are an important part of traditional Asian dietary patterns, and some of the Lactobacillus strains within these foods beverages and herbs, most notably $L$. plantarum, have been shown to have significant antioxidant activity, prevent intestinal permeability, and lower the stress-induced LPS burden [150,151]. Fermented rice products have shown antidepressant and anti-fatigue effects vs. standard rice in experimental animal models [152]. In controlled human research, L. plantarum 299v has been shown to improve pain in adults with IBS, and the same strain can reduce markers of systemic oxidative stress by $37 \%$ and markers of inflammation by $42 \%$ in adult smokers [5,153]. In animal studies maternal $L$. plantarum administration during pregnancy (and to offspring in early life - i.e. 6 months) increased microbial diversity and had anti-obesity effects later on in the life of offspring [154]. L. plantarum 299v, L. plantarum DSM 15313 and other probiotics are currently being investigated for their ability to enhance the absorption of active polyphenolic chemicals that would be of relevance to brain health $[155,156]$. It is not our desire to belabor the point concerning the interaction between food and microbes; however, there are countless other components of traditional diets that could be singled out for relevancy. The seeds of Nigella sativa (black cumin), a component of traditional dietaries in parts of Africa and South Asia, provide a clear example. Nigella sativa has been shown to protect the intestinal mucosa, suppress the growth of potentially harmful gut microbiota, and prevent LPS-induced depression-like behavior in animals [157-159]. Consider also that naturally fermented goat milk in traditional diets is higher in the protein lactoferrin [160], yet another agent that promotes the growth of bifidobacterium at the expense of potentially pathogenic 
microbes and one that can also minimize the detrimental effects of LPS [161-163]. Oral lactoferrin reduces systemic oxidative stress, and two week consumption of lactoferrin-rich colostrum has been shown to attenuate the intestinal permeability induced by exhaustive exercise in healthy athletes [164].

Even individual nutrients such as magnesium, a mineral found richly in green plant foods and the intake of which has been reported to be low in depression [165], may be a factor. In experimental studies a magnesiumdeficient diet is associated with intestinal permeability and quantitative changes to cecal bifidobacteria and lactobacilli [166]. Zinc is yet another nutrient consistently linked to depression when long-term intake is suboptimal [167], and once again it is a nutrient that can influence the diversity of the intestinal microbiota and intestinal permeability [168]. Magnesium and zinc are necessary for the activity of intestinal alkaline phosphatase (IAP), a critical enzyme involved in preserving the diversity of gut microbiota and decreasing the systemic LPS burden. IAP production itself is kept in balance by the diversity of intestinal microbiota [169,170]. The emerging research might therefore suggest that at least one bridge between healthy traditional diets and mental health includes resident microbiota. The research discussed below in the following sections of our series should only serve to strengthen this view.

\section{D-lactic and propionic acid - a cautionary tale}

Beyond the general findings of lower bifidobacteria and lactobacilli, a study involving ME (chronic fatigue syndrome) patients provides one of the most interesting and unexplored links between gut dysbiosis and mental health. Specifically, these researchers found significantly higher levels of enteroccocus and streptococcus spp. in the fecal samples of ME patients vs. controls. In particular, E. faecalis and S. sanguinis were found in higher numbers, and upon closer examination it was found that these two species manufacture significantly more D-lactic acid upon glucose exposure [98]. Although a variety of microbes in the gut, including probiotics, are also known to produce lactic acid ( $\mathrm{L}$ - and $\mathrm{D}$ - isomers), it is the elevated production of D-lactic acid that becomes a concern. D-lactic acid is broken down much more slowly than L-lactic acid, and when it begins to accumulate in the intestine it can push absorption into the blood. Other factors can enhance D-lactic acid absorption into the blood, most notably, LPS administration, intestinal permeability, psychological stress, and osmotic pressure [171,172].

Clinically, significant D-lactic acid accumulation (i.e. that leading to metabolic acidosis) is largely viewed as a rare concern, one primarily associated only with short bowel syndrome. However, with the new findings reported in ME, and separate animal studies on subtle effects of gut-derived D-lactic acid, researchers are reframing the relevance of $\mathrm{D}$-lactic acid producing gut microbes and carbohydrate fermentation. Indeed, animals with excessive carbohydrate fermentation and D-lactic acid production in the cecum exhibit anxiety, aggression and impaired memory [173-175]. The latter study also investigated plasma D-lactic acid and associated the cognitive impairment with increasing blood levels of D-lactic acid. It is noteworthy that D-lactic acid can move through the BBB and appears to interfere with neuronal energy supply via limitation of pyruvate availability. These novel studies involve low-grade D-lactic acid levels in the periphery, well below that observed in overt lactic acidosis, and the findings could be the link between contemporary SIBO, LPS, intestinal permeability and the historical 'enterosthenia'. It is entirely possible that SIBO and carbohydrate intolerance (excess undigested carbohydrate arriving at the colon) can drive D-lactic acid production, absorption, and subsequent alterations in perception of fatigue, aspects of cognition and behavior. At least one experimental study has shown that bifidobacterial surface proteins can prevent intestinal permeability and elevations in blood D-lactic acid levels subsequent to ischemia [176].

This emerging research would also suggest that selection criteria of probiotics for use in mental health clinical trials should include strains with higher L- vs. D-lactic acid production (e.g. strains of L. delbrueckii are notorious producers of D-lactic acid) $[177,178]$. Moreover, the emerging research on D-lactic acid, as induced by excessive fermentation, might also serve to warn investigators about the downsides of too much of a good thing - i.e. too much prebiotic fiber could encourage the growth of high D-lactic acid-producing species. Experimental and human research shows that excess prebiotic fiber can be an irritant to the gut barrier, increasing intestinal permeability [179]. Recently beta-glucans, often touted for prebiotic activity, were shown to increase intestinal permeability in an ex vivo animal study [180]. These findings should be taken into consideration in clinical trials regarding patient selection, and in particular those who might report carbohydrate intolerance or worsening of GI symptoms upon bran or other types of fiber consumption should be differentiated as part of trial designs. Although it is often assumed that the elevation of intestinal propionate production via prebiotics is a beneficial to the host, it is worth pointing out that systemic propionic acid reduces locomotor activity, and when it enters the brain it can induce a neuroinflammatory response and impair social behavior in animals [181]. In short, the well-meaning lay advice to supplement with prebiotics, or the wrong types of probiotics, may have unintended consequences to sub-groups of 
patients within the modern day 'entersothenia' spectrum. It is entirely possible that large doses of prebiotics or strains of $L$. delbrueckii may increase anxiety in those with, for example, co-morbid IBS and anxiety.

\section{Lessons from germ-free animals}

The original work of Cohendy in 1912, wherein he demonstrated the resiliency of chickens reared in a germfree environment [182], takes on new meaning with emerging studies involving germ-free mice. Studies have recently shown that mice reared in germ-free environments (consuming only autoclaved food) actually displayed decreased anxiety vs. animals raised with an intact intestinal microbiota (one without specific pathogens). The behavioral changes were linked to some distinct differences in neurotransmitter turnover, as well as genetic and protein expression for receptors and neuronal plasticity [183]. Moreover, the transfer of conventional microbiota to germ-free animals early in life seemed to negate the behavioral/neuronal differences, while transfer in adulthood did not reverse the behavioral signs of less anxiety in the originally germ-free animals. Other studies have reported similar findings [184-186]. One interpretation of the research is that throughout evolution, colonization with gut microbiota in early life became a critical mediator of some aspects of brain development; i.e. communication from gut-to-brain via microbes helped facilitate a higher level of subsequent vigilance and threat-based surveillance, particularly in our ability to read commensal shifts and/or the presence of potentially pathogenic microbes. Experimentally, germfree animals have a compromised ability to form memories [187], and this too may reflect lower baseline vigilance. Recall the earlier discussion regarding low levels of circulating LPS among healthy individuals, therefore it is plausible that even very low levels of LPS (sampled via "normal" microbiota) may act as a kindling to increased vigilance in the conventional animals. Indeed, gut commensal bacteria can efficiently detect the presence of a parasite (Toxoplasma gondii) in the intestine, and in turn, initiate signals for a defensive immune response - all this without the parasite actually activating specific receptors otherwise responsible for the detection of infectious pathogens [188].

The behavioral signs of decreased anxiety in germ-free animals are not necessarily a good thing, at least not in clinical terms. The experimental studies to date have mostly utilized the elevated plus maze (EPM) as the primary tool in objective behavioral assessment. Briefly, the EPM is a plus-sign-shaped apparatus that is typically set up around 2 feet off the laboratory floor; it includes two open arms (extending planks) without walls and two closed arms with walls and an open top. Exploration out from the closed areas to open arms is taken as a behavioral sign of decreased anxiety in an animal. In controlled studies the EPM is suitable in efforts to determine if an intervention (e.g. medication) can influence approach/avoidance behavior in animals, although even here its universal acceptance as a means to specifically and objectively measure anxiety has recently been called into question [189]. In the germ-free rodent studies, assuming that the mice with the healthy gut microbiota are the "otherwise well-adjusted" animals exhibiting normal baseline behavior, exploration in the open arms by the germ-free mice can also be taken as a sign of increased risk-taking; it is entirely possible that a microbefree gut encourages a higher level of risky behavior, one that might put the animal in harm's way of a predator. In one of the studies [183] the germ-free mice explored to the extreme ends of the open arms almost times more often than did the conventional mice, certainly suggesting a higher degree of risky behavior.

Therefore, the question remains, to what extent is the commensal bacteria protecting us? To what extent does it provide support in the development of an appropriate level of vigilance? Recall the importance of normal, healthy intestinal microbiota in launching a defense against T. gondii [188]. Potential relationships between T. gondii, alterations to normal intestinal microbiota, intestinal permeability, behavioral risk-taking in animals, human schizophrenia, suicide risk, and depression $[11,190,191]$ is an area worthy of investigation. How would germ-free animals react to predator odor? The amygdala is a critical structure for legitimate threat detection and vigilance, and lesions of the amygdala in primates and humans extinguish the aversion to monetary loss [192]. Germ-free mice were noted to have decreased $\mathrm{N}$-methyl-D-aspartate (NMDA) receptor mRNA expression in the central amygdala, leading to speculation of decreased amygdala activity in concert with decreased anxiety [183]. It is noteworthy that activity in the central amygdala is involved in processing the reaction to predator odor [193]. Moreover, in one study involving germfree mice, confinement stress produced higher levels of plasma corticosterone in the germ-free animals vs. those with pathogen-free microflora and in those where the gut was inhabited by bifidobacterium infantis [184]. In humans, a large cortisol response under stress is associated with decision making that is in line with immediate reward and high risk of punishment. In rodents glucocorticoid elevation predicts self-administration of psychostimulant drugs and evidence suggests that cortisol itself may be a driver of highly rewarding behavior at the expense of contemplation of risk [194].

Recently investigators have examined the effects of a Western diet (higher dietary fat, cholesterol, sugar) consumed by mice during pregnancy and determined that changes to milk quality induces systemic inflammation 
in the offspring. The inflammation and toxicity among pups nursed by Western diet-consuming mothers was even more pronounced when the parent was also raised as germ-free [195]. This highlights that certain commensal bacteria may afford a layer of protection against the effects of a Western-diet during a delicate developmental stage. The research also highlights that the relationships between diet, microbiota, metabolism, inflammation and behavior are intertwined. Reductionist approaches have certainly uncovered that microbiota alone can act as a CNS-influencing entity; however, there are a host of drawbacks in using germ-free mice, or rodents in general, to speculate on complex human gut-brain communications. Consider that shortly after germ-free mice are colonized with just a single species of commensal bacterium, researchers note marked changes to the expression of genes that govern intestinal permeability, nutrient absorption, blood vessel growth, and the metabolism of environmental toxins [196] - all of which could influence behavior via LPS and other pathways. A single strain of bifidobacterium, for example, can elevate blood tryptophan levels in animals, meanwhile tryptophan depletion during lactation can interact with stress hormones to increase anxiety later in life [197].

Interesting studies with germ-free animals have little to no clinical frame of reference in mental health - i.e. humans do not live with a sterile GI tract while consuming exclusively autoclaved food; however, they do indicate that developmentally our resident microbiota, or the absence thereof, can have a long-standing influence on brain functioning and behavior. Researchers might ponder if long-term mental health consequences could be associated with the routine prophylactic use of broadspectrum antimicrobials among pre-term infants. This practice, one that has been questioned recently [198], sets up a pseudo-germ-free situation in premature infants, and it can now be yet one more factor to consider in the link between pre-term birth and mental illness. Recently, a large epidemiological study using the Swedish Medical Birth Register - 1.3 million people - has found that premature birth is associated with a $30 \%$ higher risk of depression and a $270 \%$ increase in bipolar depression later in life [199]. At some point in the future, with more detailed investigations, the germ-free studies may be of relevance in bridging the research on the immune benefits of prenatal exposure to probiotics, and on the other side, the increased risk of serious mental illness (in adult offspring) subsequent to infection during pregnancy [200]. Of course, there is also the issue of intestinal microbiota and their effects on the elimination of environmental toxins. When animals are exposed to low doses of bisphenol A (BPA) during gestation, lactation and nursing, there are subsequently marked increases in later-life anxiety accompanied by alterations in gene expression within the amygdala [201]. With the recent discovery that oral probiotics co-administered with BPA can dramatically reduce the systemic burden of this and other environmental toxins (increasing elimination via fecal route), it becomes difficult to view the 'real world' gut-brain connection in germ-free isolation. The influence of probiotic administration on both the developing immune system and metabolism during the introduction of foods (weaning diet) is an exciting area of research, with preliminary results indicating long-term systemic effects [202].

\section{The stage is set}

The research discussed here in Part II can be considered contextual; before examining more clinically relevant investigations on behavior and microbiota, it seems vital to underscore the fact that any discussion of microbiota and mental health, or probiotics as an intervention in behavioral medicine, is not akin to discussions of alprazolam, fluoxetine, etc. There are a myriad of ways in which the microbes of the intestinal tract may interact with environmental factors, most notably those of the dietary. As described here in Part II, some of Ferraro and Kilman's 1933 'wish list' of research has been initiated, including the effects of intestinal permeability and dietary alterations in relation to microbes and mental health. In Part III we will turn our attention to the other aspects, including purposeful alterations of the intestinal microbiota (dysbiosis), the unresolved effects of intestinalderived toxins, and the experimental and clinical application of factors of bacteriology (probiotics).

\section{Competing interests}

$A C B$ and EMS have no competing interests. $A C L$ has received consulting fees from Genuine Health, Toronto, Canada.

\section{Authors' contributions}

$A C B, A C L$ and $E M S$ contributed equal time and effort in the investigation, research and drafting of this manuscript. All authors read and approved the final manuscript.

\section{Author details}

${ }^{1}$ Complex Chronic Diseases Program, BC Women's Hospital and Health Centre, B223A-4500 Oak Street, Vancouver, BC V6H 3N1, Canada. ${ }^{2}$ CAMNR, 775 Blithedale Avenue, Suite 364, Mill Valley, CA 94941, USA. ${ }^{3}$ Harvard Medical School and Massachusetts General Hospital, 40 Crescent St., Suite 201, Waltham, MA 02453, USA.

Received: 7 February 2013 Accepted: 10 March 2013

Published: 14 March 2013

\section{References}

1. Ferrao A, Kilman JE: Experimental toxic approach to mental illness. Psychiatr Q 1933, 7:115-153.

2. Logan AC, Venket Rao A, Irani D: Chronic fatigue syndrome: lactic acid bacteria may be of therapeutic value. Med Hypotheses 2003, 60:915-923.

3. Logan AC, Katzman M: Major depressive disorder: probiotics may be an adjuvant therapy. Med Hypotheses 2005, 64:533-538.

4. Reichenberg A, Yirmiya R, Schuld A, Kraus T, Haack M, Morag A, Pollmächer T: Cytokine-associated emotional and cognitive disturbances in humans. Arch Gen Psychiatry 2001, 58:445-452. 
5. Naruszewicz M, Johansson ML, Zapolska-Downar D, Bukowska H: Effect of Lactobacillus plantarum $299 \mathrm{v}$ on cardiovascular disease risk factors in smokers. Am J Clin Nutr 2002, 76:1249-1255.

6. Lyte M, Varcoe JJ, Bailey MT: Anxiogenic effect of subclinical bacterial infection in mice in the absence of overt immune activation. Physiol Behav 1998, 65:63-68.

7. Benton D, Williams C, Brown A: Impact of consuming a milk drink containing a probiotic on mood and cognition. Eur J Clin Nutr 2007, 61:355-361.

8. Rao AV, Bested AC, Beaulne TM, Katzman MA, lorio C, Berardi JM, et al: A randomized, double-blind, placebo-controlled pilot study of a probiotic in emotional symptoms of chronic fatigue syndrome. Gut Pathog 2009, 1:6.

9. Messaoudi M, Lalonde $\mathrm{R}$, Violle $\mathrm{N}$, Javelot $\mathrm{H}$, Desor D, Nejdi A, et al: Assessment of psychotropic-like properties of a probiotic formulation (Lactobacillus helveticus R0052 and Bifidobacterium longum R0175) in rats and human subjects. Br J Nutr 2011, 105:755-764.

10. Dinan TG, Quigley EM: Probiotics in the treatment of depression: science or science fiction? Aust N Z J Psychiatry 2011, 45:1023-1025.

11. Severance EG, Alaedini A, Yang S, Halling M, Gressitt KL, Stallings CR, Origoni AE, Vaughan C, Khushalani S, Leweke FM, Dickerson FB, Yolken RH: Gastrointestinal inflammation and associated immune activation in schizophrenia. Schizophr Res 2012, 138:48-53.

12. Critchfield JW, van Hemert S, Ash M, Mulder L, Ashwood P: The potential role of probiotics in the management of childhood autism spectrum disorders. Gastroenterol Res Pract 2011, 2011:161358.

13. Bijl RV, de Graaf R, Hiripi E, Kessler RC, Kohn R, Offord DR, Ustun TB, Vicente B, Vollebergh WA, Walters EE, Wittchen HU: The prevalence of treated and untreated mental disorders in five countries. Health Aff 2003, 22:122-133.

14. Dowlati Y, Herrmann N, Swardfager W, Liu H, Sham L, Reim EK, Lanctôt KL: A meta-analysis of cytokines in major depression. Biol Psychiatry 2010, 67:446-457.

15. Rawdin BS, Mellon SH, Dhabhar FS, Epel ES, Puterman E, Su Y, Burke HM, Reus VI, Rosser R, Hamilton SP, Nelson JC, Wolkowitz OM: Dysregulated relationship of inflammation and oxidative stress in major depression. Brain Behav Immun 2012. doi:10.1016/j.bbi.2012.11.011.

16. Gibson SA, Korade Ž, Shelton RC: Oxidative stress and glutathione response in tissue cultures from persons with major depression. J Psychiatr Res 2012, 46:1326-1332.

17. Messay B, Lim A, Marsland AL: Current understanding of the bi-directional relationship of major depression with inflammation. Biol Mood Anxiety Disord 2012, 2:4.

18. Hannestad J, Gallezot JD, Schafbauer T, Lim K, Kloczynski T, Morris ED, Carson RE, Ding YS, Cosgrove KP: Endotoxin-induced systemic inflammation activates microglia: $\left[{ }^{11} \mathrm{C}\right] \mathrm{PBR} 28$ positron emission tomography in nonhuman primates. Neurolmage 2012, 63:232-239.

19. Prager G, Hadamitzky M, Engler A, Doenlen R, Wirth T, Pacheco-López G, Krügel U, Schedlowski M, Engler H: Amygdaloid Signature of Peripheral Immune Activation by Bacterial Lipopolysaccharide or Staphylococcal Enterotoxin B. J Neuroimmune Pharmacol 2013, 8:42-50.

20. Grigoleit JS, Kullmann JS, Wolf OT, Hammes F, Wegner A, Jablonowski S, Engler H, Gizewski E, Oberbeck R, Schedlowski M: Dose-dependent effects of endotoxin on neurobehavioral functions in humans. PLOS One 2011 6:e28330.

21. Kullmann JS, Grigoleit JS, Lichte $P$, Kobbe P, Rosenberger C, Banner C, Wolf OT, Engler H, Oberbeck R, Elsenbruch S, Bingel U, Forsting M, Gizewski ER, Schedlowski M: Neural response to emotional stimuli during experimental human endotoxemia. Hum Brain Mapp 2012. doi:10.1002/ hbm.22063.

22. Dellagioia N, Devine L, Pittman B, Hannestad J: Bupropion pre-treatment of endotoxin-induced depressive symptoms. Brain Behav Immun 2012. doi:10.1016/j.bbi.2012.10.008.

23. Benson S, Kattoor J, Wegner A, Hammes F, Reidick D, Grigoleit JS, Engler H, Oberbeck R, Schedlowski M, Elsenbruch S: Acute experimental endotoxemia induces visceral hypersensitivity and altered pain evaluation in healthy humans. Pain 2012, 153:794-799.

24. Moreira AP, Texeira TF, Ferreira AB, Peluzio Mdo C, Alfenas RC: Influence of a high-fat diet on gut microbiota, intestinal permeability and metabolic endotoxaemia. Br J Nutr 2012, 108:801-809.

25. Sun L, Yu Z, Ye X, Zou S, Li H, Yu D, Wu H, Chen Y, Dore J, Clément K, Hu FB, $\mathrm{Lin} X$ : A marker of endotoxemia is associated with obesity and related metabolic disorders in apparently healthy Chinese. Diabetes Care 2010, 33:1925-1932.

26. Miller MA, McTernan PG, Harte AL, Silva NF, Strazzullo P, Alberti KG, Kumar S, Cappuccio FP: Ethnic and sex differences in circulating endotoxin levels: A novel marker of atherosclerotic and cardiovascular risk in a British multi-ethnic population. Atherosclerosis 2009, 203:494-502.

27. Pussinen PJ, Havulinna AS, Lehto M, Sundvall J, Salomaa V: Endotoxemia is associated with an increased risk of incident diabetes. Diabetes Care 2011, 34:392-397.

28. Vaishnava S, Hooper LV: Alkaline phosphatase: keeping the peace at the gut epithelial surface. Cell Host Microbe 2007, 2:365-367.

29. Kour K, Bani S: Chicoric acid regulates behavioral and biochemical alterations induced by chronic stress in experimental Swiss albino mice. Pharmacol Biochem Behav 2011, 99:342-348.

30. Engler H, Doenlen R, Engler A, Riether C, Prager G, Niemi MB, PachecoLópez G, Krügel U, Schedlowski M: Acute amygdaloid response to systemic inflammation. Brain Behav Immun 2011, 25:1384-1392.

31. Haba R, Shintani N, Onaka Y, Wang H, Takenaga R, Hayata A, Baba A, Hashimoto H: Lipopolysaccharide affects exploratory behaviors toward novel objects by impairing cognition and/or motivation in mice: Possible role of activation of the central amygdala. Behav Brain Res 2012, 228:423-431.

32. Miura H, Shirokawa T, Isobe $K$, Ozaki N: Shifting the balance of brain tryptophan metabolism elicited by isolation housing and systemic administration of lipopolysaccharide in mice. Stress 2009, 12:206-214.

33. Dobos N, de Vries EF, Kema IP, Patas K, Prins M, Nijholt IM, Dierckx RA, Korf J, den Boer JA, Luiten PG, Eisel UL: The role of indoleamine 2,3-dioxygenase in a mouse model of neuroinflammation-induced depression. Alzheimers Dis 2012, 28:905-915.

34. Salazar A, Gonzalez-Rivera BL, Redus L, Parrott JM, O'Connor JC: Indoleamine 2,3-dioxygenase mediates anhedonia and anxiety-like behaviors caused by peripheral lipopolysaccharide immune challenge. Horm Behav 2012, 62:202-209.

35. Kuc D, Zgrajka W, Parada-Turska J, Urbanik-Sypniewska T, Turski WA: Micromolar concentration of kynurenic acid in rat small intestine. Amino Acids 2008, 35:503-505

36. Turski MP, Turska M, Zgrajka W, Kuc D, Turski WA: Presence of kynurenic acid in food and honeybee products. Amino Acids 2009, 36:75-80.

37. Lapin IP: Antagonism of kynurenic acid to anxiogens in mice. Life SCl 1998, 63:PL231-PL236.

38. Murray CL, Skelly DT, Cunningham C: Exacerbation of CNS inflammation and neurodegeneration by systemic LPS treatment is independent of circulating IL-1 $\beta$ and IL-6. J Neuroinflammation 2011, 8:50.

39. Cardoso FL, Kittel A, Veszelka S, Palmela I, Tóth A, Brites D, Deli MA, Brito MA: Exposure to lipopolysaccharide and/or unconjugated bilirubin impair the integrity and function of brain microvascular endothelial cells. PLOS One 2012, 7:e35919.

40. Erickson MA, Hansen K, Banks WA: Inflammation-induced dysfunction of the low-density lipoprotein receptor-related protein-1 at the bloodbrain barrier: protection by the antioxidant $\mathrm{N}$-acetylcysteine. Brain Behav Immun 2012, 26:1085-1094.

41. Gao Y, Huang C, Zhao K, Ma L, Qiu X, Zhang L, Xiu Y, Chen L, Lu W, Huang C, Tang Y, Xiao Q: Depression as a risk factor for dementia and mild cognitive impairment: a meta-analysis of longitudinal studies. Int J Geriatr Psychiatry 2012. doi:10.1002/gps.3845.

42. Ramirez SH, Haskó J, Skuba A, Fan S, Dykstra H, McCormick R, Reichenbach N Krizbai I, Mahadevan A, Zhang M, Tuma R, Son YJ, Persidsky Y: Activation of cannabinoid receptor 2 attenuates leukocyte-endothelial cell interactions and blood-brain barrier dysfunction under inflammatory conditions. J Neurosci 2012, 32:4004-4016.

43. Donovan I, Grundy G: Endocannabinoid modulation of jejunal afferent responses to LPS. Neurogastroenterol Motil 2012, 24:956-e465.

44. Audet MC, Jacobson-Pick S, Wann BP, Anisman H: Social defeat promotes specific cytokine variations within the prefrontal cortex upon subsequent aggressive or endotoxin challenges. Brain Behav Immun 2011, 25:1197-1205

45. Johnson AV, Goodall E: On the action of the blood serum from cases of acute mental disorder on B. coli communis. Br Med J 1904, 1:826-827.

46. Maes M, Kubera M, Leunis JC, Berk M, Geffard M, Bosmans E: In depression, bacterial translocation may drive inflammatory responses, oxidative and nitrosative stress (O\&NS), and autoimmune responses directed against 
O\&NS-damaged neoepitopes. Acta Psychiatr Scand 2012. doi:10.1111/ j.1600-0447.2012.01908.x

47. Maes M, Kubera M, Leunis JC, Berk M: Increased IgA and IgM responses against gut commensals in chronic depression: further evidence for increased bacterial translocation or leaky gut. J Affect Disord 2012, 141:55-62.

48. Maes M, Kubera M, Leunis JC: The gut-brain barrier in major depression: intestinal mucosal dysfunction with an increased translocation of LPS from gram negative enterobacteria (leaky gut) plays a role in the inflammatory pathophysiology of depression. Neuro Endocrinol Lett 2008, 29:117-124.

49. Leclercq S, Cani PD, Neyrinck AM, Stärkel P, Jamar F, Mikolajczak M, Delzenne NM, de Timary P: Role of intestinal permeability and inflammation in the biological and behavioral control of alcoholdependent subjects. Brain Behav Immun 2012, 26:911-918.

50. Teixeira TF, Souza NC, Chiarello PG, Franceschini SC, Bressan J, Ferreira CL, Peluzio Mdo C: Intestinal permeability parameters in obese patients are correlated with metabolic syndrome risk factors. Clin Nutr 2012, 31:735-740.

51. Gummesson A, Carlsson LM, Storlien LH, Bäckhed F, Lundin P, Löfgren L, Stenlöf K, Lam YY, Fagerberg B, Carlsson B: Intestinal permeability is associated with visceral adiposity in healthy women. Obesity 2011, 19:2280-2282

52. Goebel A, Buhner S, Schedel R, Lochs H, Sprotte G: Altered intestinal permeability in patients with primary fibromyalgia and in patients with complex regional pain syndrome. Rheumatology 2008, 47:1223-1227.

53. Maes M, Twisk FN, Kubera M, Ringel K, Leunis JC, Geffard M: Increased IgA responses to the LPS of commensal bacteria is associated with inflammation and activation of cell-mediated immunity in chronic fatigue syndrome. J Affect Disord 2012, 136:909-917.

54. de Magistris L, Familiari V, Pascotto A, Sapone A, Frolli A, lardino P, Carteni M, De Rosa M, Francavilla R, Riegler G, Militerni R, Bravaccio C: Alterations of the intestinal barrier in patients with autism spectrum disorders and in their first-degree relatives. J Pediatr Gastroenterol Nutr 2010, 51:418-424.

55. Turck FB: The mechanism of intestinal atony in children - etiology and treatment. NY State J Med 1918, 18:1-6.

56. Alonso C, Guilarte M, Vicario M, Ramos L, Rezzi S, Martínez C, Lobo B, Martin FP, Pigrau M, González-Castro AM, Gallart M, Malagelada JR, Azpiroz F, Kochhar S, Santos J: Acute experimental stress evokes a differential genderdetermined increase in human intestinal macromolecular permeability. Neurogastroenterol Motil 2012, 24:740-746. e348-9.

57. van Wijck K, Lenaerts K, Grootjans J, Wijnands KA, Poeze M, van Loon LJ, Dejong $\mathrm{CH}$, Buurman WA: Physiology and pathophysiology of splanchnic hypoperfusion and intestinal injury during exercise: strategies for evaluation and prevention. Am J Physiol Gastrointest Liver Physiol 2012, 303:G155-G168.

58. Ruuskanen A, Kaukinen K, Collin P, Huhtala H, Valve R, Mäki M, Luostarinen L: Positive serum antigliadin antibodies without celiac disease in the elderly population: does it matter? Scand J Gastroenterol 2010, 45:1197-1202

59. Fitzgerald EF, Belanger EE, Gomez Ml, Cayo M, McCaffrey RJ, Seegal RF, Jansing RL, Hwang SA, Hicks HE: Polychlorinated biphenyl exposure and neuropsychological status among older residents of upper Hudson River communities. Environ Health Perspect 2008, 116:209-215.

60. Choi YJ, Seelbach MJ, Pu H, Eum SY, Chen L, Zhang B, Hennig B, Toborek M: Polychlorinated biphenyls disrupt intestinal integrity via NADPH oxidaseinduced alterations of tight junction protein expression. Environ Health Perspect 2010, 118:976-981

61. Seelbach M, Chen L, Powell A, Choi YJ, Zhang B, Hennig B, Toborek M: Polychlorinated biphenyls disrupt blood-brain barrier integrity and promote brain metastasis formation. Environ Health Perspect 2010, 118:479-484.

62. Oishi K, Sato T, Yokoi W, Yoshida Y, Ito M, Sawada H: Effect of probiotics, Bifidobacterium breve and Lactobacillus casei, on bisphenol A exposure in rats. Biosci Biotechnol Biochem 2008, 72:1409-1415.

63. Fischbach R: Gastric acid production and iron metabolism in depressive states. Pharmakopsychiatr Neuropsychopharmakol 1973, 6:247-251.

64. Nakagawa T, Kawano T, Nagato H, Kimura M, Takayama T: A clinical and psychophysiological study of depression in internal medicine. Psychosomatics 1976, 17:173-179.
65. Lombardo L, Foti M, Ruggia O, Chiecchio A: Increased incidence of small intestinal bacterial overgrowth during proton pump inhibitor therapy. Clin Gastroenterol Hepatol 2010, 8:504-508.

66. Bures J, Cyrany J, Kohoutova D, Förstl M, Rejchrt S, Kvetina J, et al: Small intestinal bacterial overgrowth syndrome. World J Gastroenterol 2010, 16:2978-2990.

67. Pyleris E, Giamarellos-Bourboulis EJ, Tzivras D, Koussoulas V, Barbatzas C, Pimentel M: The prevalence of overgrowth by aerobic bacteria in the small intestine by small bowel culture: relationship with irritable bowel syndrome. Dig Dis Sci 2012, 57:1321-1329.

68. Madrid AM, Poniachik J, Quera R, Defilippi C: Small intestinal clustered contractions and bacterial overgrowth: a frequent finding in obese patients. Dig Dis Sci 2011, 56:155-160.

69. Pimentel M, Wallace D, Hallegua D, Chow E, Kong Y, Park S, Lin HC: A link between irritable bowel syndrome and fibromyalgia may be related to findings on lactulose breath testing. Ann Rheum Dis 2004, 63:450-452.

70. Rana S, Bhansali A, Bhadada S, Sharma S, Kaur J, Singh K: Orocecal transit time and small intestinal bacterial overgrowth in type 2 diabetes patients from North India. Diabetes Technol Ther 2011, 13:1115-1120.

71. Addolorato G, Mirijello A, D'Angelo C, Leggio L, Ferrulli A, Abenavoli L, et al: State and trait anxiety and depression in patients affected by gastrointestinal diseases: psychometric evaluation of 1641 patients referred to an internal medicine outpatient setting. Int J Clin Pract 2008, 62:1063-1069.

72. Kim KM, Kim BT, Lee DJ, Park SB, Joo NS, Kim YS, Kim KN: Erosive esophagitis may be related to small intestinal bacterial overgrowth. Scand J Gastroenterol 2012, 47:493-498.

73. Heading RC, Mönnikes H, Tholen A, Schmitt H: Prediction of response to PPI therapy and factors influencing treatment outcome in patients with GORD: a prospective pragmatic trial using pantoprazole. BMC Gastroenterol 2011, 11:52.

74. Pimentel M, Hallegua D, Chow EJ, Wallace D, Bonorris G, Lin HC: Eradication of small intestinal bacterial overgrowth decreases symptoms in chronic fatigue syndrome: a double blind, randomized study. Gastroenterology 2000, 118:A414.

75. Toskes PP: Bacterial overgrowth of the gastrointestinal tract. Adv Intern Med 1993, 38:387-407.

76. Lauritano EC, Valenza V, Sparano L, Scarpellini E, Gabrielli M, Cazzato A, et al: Small intestinal bacterial overgrowth and intestinal permeability. Scand J Gastroenterol 2010, 45:1131-1132.

77. Wang SX, Wu WC: Effects of psychological stress on small intestinal motility and bacteria and mucosa in mice. World J Gastroenerol 2005, 11:2016-2021.

78. Morris TH, Sorensen SH, Turkington J, Batt RM: Diarrhoea and increased intestinal permeability in laboratory beagles associated with proximal small intestinal bacterial overgrowth. Lab Anim 1994, 28:313-319.

79. Barrett JS, Canale KE, Gearry RB, Irving PM, Gibson PR: Probiotic effects on intestinal fermentation patterns in patients with irritable bowel syndrome. World J Gastroenterol 2008, 14:5020-5024

80. Ralph HJ, Volker DH, Chin J: Effects of omega-3 fatty acid deficiency on rat intestinal structure and microbiology. Asia Pac J Clin Nutr 2004, 13(Suppl):S79

81. Fuller RA, Irvine KN, Devine-Wright P, Warren PH, Gaston KJ: Psychological benefits of greenspace increase with biodiversity. Biol Lett 2007, 3:390-394.

82. Luck GW, Davidson P, Boxall D, Smallbone L: Relations between urban bird and plant communities and human well-being and connection to nature. Conservation Biol 2011, 25:816-826.

83. Karlsson C, Ahrné S, Molin G, Berggren A, Palmquist I, Fredrikson GN, Jeppsson B: Probiotic therapy to men with incipient arteriosclerosis initiates increased bacterial diversity in colon: a randomized controlled trial. Atherosclerosis 2010, 208:228-233.

84. Hanski I, von Hertzen L, Fyhrquist N, Koskinen K, Torppa K, Laatikainen T, Karisola P, Auvinen P, Paulin L, Mäkelä MJ, Vartiainen E, Kosunen TU, Alenius H, Haahtela T: Environmental biodiversity, human microbiota, and allergy are interrelated. Proc Natl Acad Sci USA 2012, 109:8334-8339.

85. Vitali B, Minervini G, Rizzello CG, Spisni E, Maccaferri S, Brigidi P, Gobbetti M, Di Cagno R: Novel probiotic candidates for humans isolated from raw fruits and vegetables. Food Microbiol 2012, 31:116-125.

86. Benno Y, Suzuki K, Suzuki K, Narisawa K, Bruce WR, Mitsuoka T: Comparison of the fecal microflora in rural Japanese and urban Canadians. Microbiol Immunol 1986, 30:521-532. 
87. Benno Y, Endo K, Mizutani T, Namba Y, Komori T, Mitsuoka T: Comparison of fecal microflora of elderly persons in rural and urban areas of Japan. Appl Environ Microbiol 1989, 55:1100-1105.

88. De Filippo C, Cavalieri D, Di Paola M, Ramazzotti M, Poullet JB, Massart S, Collini S, Pieraccini G, Lionetti P: Impact of diet in shaping gut microbiota revealed by a comparative study in children from Europe and rural Africa. Proc Natl Acad Sci USA 2010, 107:14691-14696.

89. Yatsunenko T, Rey FE, Manary MJ, Trehan I, Dominguez-Bello MG, Contreras M, Magris M, Hidalgo G, Baldassano RN, Anokhin AP, Heath AC, Warner B, Reeder J, Kuczynski J, Caporaso JG, Lozupone CA, Lauber C, Clemente JC, Knights D, Knight R, Gordon Jl: Human gut microbiome viewed across age and geography. Nature 2012, 486:222-227.

90. Moschen AR, Wieser $\mathrm{V}$, Tilg H: Dietary factors: major regulators of the gut's microbiota. Gut Liver 2012, 6:411-416.

91. Knowles SR, Nelson EA, Palombo EA: Investigating the role of perceived stress on bacterial flora activity and salivary cortisol secretion: a possible mechanism underlying susceptibility to illness. Biol Psychol 2008, 77:132-137.

92. Lahtinen SJ, Tammela L, Korpela J, Parhiala R, Ahokoski H, Mykkänen H, Salminen SJ: Probiotics modulate the Bifidobacterium microbiota of elderly nursing home residents. AGE 2009, 31:59-66.

93. Ahmed M, Prasad J, Gill H, Stevenson L, Gopal P: Impact of consumption of different levels of Bifidobacterium lactis HN019 on the intestinal microflora of elderly human subjects. $J$ Nutr Health Aging 2007, 11:26-31.

94. Qin J, Li Y, Cai Z, Li S, Zhu J, Zhang F, Liang S, Zhang W, Guan Y, Shen D, Peng $Y$, Zhang D, Jie Z, Wu W, Qin Y, Xue W, Li J, Han L, Lu D, Wu P, Dai Y, Sun X, Li Z, Tang A, Zhong S, Li X, Chen W, Xu R, Wang M, Feng Q, Gong M, Yu J, Zhang Y, Zhang M, Hansen T, Sanchez G, Raes J, Falony G, Okuda S, Almeida M, LeChatelier E, Renault P, Pons N, Batto JM, Zhang Z, Chen H, Yang R, Zheng W, Li S, Yang H, Wang J, Ehrlich SD, Nielsen R, Pedersen O, Kristiansen K, Wang J: A metagenome-wide association study of gut microbiota in type 2 diabetes. Nature 2012, 490:55-60.

95. Carroll IM, Ringel-Kulka T, Siddle JP, Ringel Y: Alterations in composition and diversity of the intestinal microbiota in patients with diarrheapredominant irritable bowel syndrome. Neurogastroenterol Motil 2012, 24:521-530. e248.

96. Chassard C, Dapoigny M, Scott KP, Crouzet L, Del'homme C, Marquet $P$, Martin JC, Pickering G, Ardid D, Eschalier A, Dubray C, Flint HJ, BernalierDonadille A: Functional dysbiosis within the gut microbiota of patients with constipated-irritable bowel syndrome. Aliment Pharmacol Ther 2012, 35:828-838.

97. Ferrer M, Ruiz A, Lanza F, Haange SB, Oberbach A, Till H, Bargiela R, Campoy C, Segura MT, Richter M, von Bergen M, Seifert J, Suarez A: Microbiota from the distal guts of lean and obese adolescents exhibit partial functional redundancy besides clear differences in community structure. Environ Microbio/ 2013, 15:211-226.

98. Sheedy JR, Wettenhall RE, Scanlon D, Gooley PR, Lewis DP, McGregor N, Stapleton Dl, Butt HL, de Meirleir KL: Increased d-lactic Acid intestinal bacteria in patients with chronic fatigue syndrome. In Vivo 2009, 23:621-628.

99. Cani PD, Neyrinck AM, Fava F, Knauf C, Burcelin RG, Tuohy KM, Gibson GR, Delzenne NM: Selective increases of bifidobacteria in gut microflora improve high-fat-diet-induced diabetes in mice through a mechanism associated with endotoxaemia. Diabetologia 2007, 50:2374-2383.

100. Pendyala S, Walker JM, Holt PR: A high-fat diet is associated with endotoxemia that originates from the gut. Gastroenterology 2012, 142:1100-1101. e2.

101. Fava F, Gitau R, Griffin BA, Gibson GR, Tuohy KM, Lovegrove JA: The type and quantity of dietary fat and carbohydrate alter faecal microbiome and short-chain fatty acid excretion in a metabolic syndrome 'at-risk' population. Int J Obes 2013, 37:216-223.

102. Cani PD, Amar J, Iglesias MA, Poggi M, Knauf C, Bastelica D, Neyrinck AM, Fava F, Tuohy KM, Chabo C, Waget A, Delmée E, Cousin B, Sulpice T, Chamontin B, Ferrières J, Tanti JF, Gibson GR, Casteilla L, Delzenne NM, Alessi MC, Burcelin R: Metabolic endotoxemia initiates obesity and insulin resistance. Diabetes 2007, 56:1761-1772.

103. Davidson TL, Monnot A, Neal AU, Martin AA, Horton JJ, Zheng W: The effects of a high-energy diet on hippocampal-dependent discrimination performance and blood-brain barrier integrity differ for diet-induced obese and diet-resistant rats. Physiol Behav 2012, 107:26-33.
104. Freeman LR, Granholm AC: Vascular changes in rat hippocampus following a high saturated fat and cholesterol diet. J Cereb Blood Flow Metab 2012, 32:643-653.

105. Jacka FN, Mykletun A, Berk M, Bjelland I, Tell GS: The association between habitual diet quality and the common mental disorders in communitydwelling adults: the Hordaland Health study. Psychosom Med 2011, 73:483-490.

106. Jacka FN, Pasco JA, Mykletun A, Williams LJ, Hodge AM, O'Reilly SL, Nicholson GC, Kotowicz MA, Berk M: Association of Western and traditional diets with depression and anxiety in women. Am J Psychiatry 2010, 167:305-311.

107. Akbaraly TN, Brunner EJ, Ferrie JE, Marmot MG, Kivimaki M, Singh-Manoux A: Dietary pattern and depressive symptoms in middle age. $\mathrm{Br} J$ Psychiatry 2009, 195:408-413.

108. Sánchez-Villegas A, Delgado-Rodríguez M, Alonso A, Schlatter J, Lahortiga F, Serra Majem L, Martínez-González MA: Association of the Mediterranean dietary pattern with the incidence of depression: the Seguimiento Universidad de Navarra/University of Navarra follow-up (SUN) cohort. Arch Gen Psychiatry 2009, 66:1090-1098.

109. Sánchez-Villegas A, Toledo E, de Irala J, Ruiz-Canela M, Pla-Vidal J, MartínezGonzález MA: Fast-food and commercial baked goods consumption and the risk of depression. Public Health Nutr 2012, 15:424-432.

110. Crawford GB, Khedkar A, Flaws JA, Sorkin JD, Gallicchio L: Depressive symptoms and self-reported fast-food intake in midlife women. Prev Med 2011, 52:254-257.

111. Hirth JM, Rahman M, Berenson AB: The association of posttraumatic stress disorder with fast food and soda consumption and unhealthy weight loss behaviors among young women. J Womens Health 2011, 20:1141-1149.

112. Laugerette F, Furet JP, Debard C, Daira P, Loizon E, Géloën A, Soulage CO, Simonet C, Lefils-Lacourtablaise J, Bernoud-Hubac N, Bodennec J, Peretti N, Vidal H, Michalski MC: Oil composition of high-fat diet affects metabolic inflammation differently in connection with endotoxin receptors in mice. Am J Physiol Endocrinol Metab 2012, 302:E374-E386.

113. Willemsen LE, Koetsier MA, Balvers M, Beermann C, Stahl B, van Tol EA: Polyunsaturated fatty acids support epithelial barrier integrity and reduce IL-4 mediated permeability in vitro. Eur J Nutr 2008, 47:183-191.

114. Lam YY, Ha CW, Campbell CR, Mitchell AJ, Dinudom A, Oscarsson J, Cook DI, Hunt NH, Caterson ID, Holmes AJ, Storlien LH: Increased gut permeability and microbiota change associate with mesenteric fat inflammation and metabolic dysfunction in diet-induced obese mice. PLoS One 2012, 7:e34233.

115. Wall R, Marques TM, O'Sullivan O, Ross RP, Shanahan F, Quigley EM, Dinan TG, Kiely B, Fitzgerald GF, Cotter PD, Fouhy F, Stanton C: Contrasting effects of Bifidobacterium breve NCIMB 702258 and Bifidobacterium breve DPC 6330 on the composition of murine brain fatty acids and gut microbiota. Am J Clin Nutr 2012, 95:1278-1287.

116. Bergheim I, Weber S, Vos M, Krämer S, Volynets V, Kaserouni S, McClain CJ, Bischoff SC: Antibiotics protect against fructose-induced hepatic lipid accumulation in mice: role of endotoxin. Hepatol 2008, 48:983-992.

117. Duffey KJ, Popkin BM: High-fructose corn syrup: is this what's for dinner? Am J Clin Nutr 2008, 88:1722S-1732S.

118. Peet M: International variations in the outcome of schizophrenia and the prevalence of depression in relation to national dietary practices: an ecological analysis. Br J Psychiatry 2004, 184:404-408.

119. Westover AN, Marangell LB: A cross-national relationship between sugar consumption and major depression? Depress Anxiety 2002, 16:118-120.

120. Varea V, de Carpi JM, Puig C, Alda JA, Camacho E, Ormazabal A, Artuch R, Gómez L: Malabsorption of carbohydrates and depression in children and adolescents. J Pediatr Gastroenterol Nutr 2005, 40:561-565.

121. Ledochowski M, Widner B, Bair H, Probst T, Fuchs D: Fructose- and sorbitolreduced diet improves mood and gastrointestinal disturbances in fructose malabsorbers. Scand J Gastroenterol 2000, 35:1048-1052.

122. Ledochowski M, Widner B, Murr C, Sperner-Unterweger B, Fuchs D: Fructose malabsorption is associated with decreased plasma tryptophan. Scand J Gastroenterol 2001, 36:367-371.

123. Wang HY, Qi LW, Wang CZ, Li P: Bioactivity enhancement of herbal supplements by intestinal microbiota focusing on ginsenosides. Am J Chin Med 2011, 39:1103-1115.

124. Del Rio D, Stalmach A, Calani L, Crozier A: Bioavailability of coffee chlorogenic acids and green tea flavan-3-ols. Nutrients 2010, 2:820-833. 
125. Renouf M, Guy PA, Marmet C, Fraering AL, Longet K, Moulin J, Enslen M, Barron D, Dionisi F, Cavin C, Williamson G, Steiling H: Measurement of caffeic and ferulic acid equivalents in plasma after coffee consumption: small intestine and colon are key sites for coffee metabolism. Mol Nutr Food Res 2010, 54:760-766.

126. Stoupi S, Williamson G, Drynan JW, Barron D, Clifford MN: A comparison of the in vitro biotransformation of (-)-epicatechin and procyanidin B2 by human faecal microbiota. Mol Nutr Food Res 2010, 54:747-759.

127. Gross G, Jacobs DM, Peters $S$, et al: In vitro bioconversion of polyphenols from black tea and red wine/grape juice by human intestinal microbiota displays strong inter-individual variability. J Agric Food Chem 2010, 58:10236-10246.

128. Devore EE, Kang JH, Breteler MM, Grodstein F: Dietary intakes of berries and flavonoids in relation to cognitive decline. Ann Neurol 2012, 72:135-143.

129. Nehlig $A$ : The neuroprotective effects of cocoa flavanol and its influence on cognitive performance. Br J Clin Pharmacol 2013, 75:716-727.

130. Lucas M, Mirzaei F, Pan A, Okereke OI, Willett WC, O'Reilly É, Koenen K, Ascherio A: Coffee, caffeine, and risk of depression among women. Arch Intern Med 2011, 171:1571-1578.

131. Niu K, Hozawa A, Kuriyama S, Ebihara S, Guo H, Nakaya N, Ohmori-Matsuda K, Takahashi H, Masamune Y, Asada M, Sasaki S, Arai H, Awata S, Nagatomi R, Tsuji I: Green tea consumption is associated with depressive symptoms in the elderly. Am J Clin Nutr 2009, 90:1615-1622.

132. Ng TP, Chiam PC, Lee T, Chua HC, Lim L, Kua EH: Curry consumption and cognitive function in the elderly. Am J Epidemiol 2006, 164:898-906.

133. Jin JS, Touyama M, Hisada T, Benno Y: Effects of green tea consumption on human fecal microbiota with special reference to Bifidobacterium species. Microbiol Immunol 2012, 56:729-739.

134. Vendrame S, Guglielmetti S, Riso P, Arioli S, Klimis-Zacas D, Porrini M: Six-week consumption of a wild blueberry powder drink increases bifidobacteria in the human gut. Agric Food Chem 2011, 59:12815-12820.

135. Tzounis X, Rodriguez-Mateos A, Vulevic J, Gibson GR, Kwik-Uribe C, Spencer JP: Prebiotic evaluation of cocoa-derived flavanols in healthy humans by using a randomized, controlled, double-blind, crossover intervention study. Am J Clin Nutr 2011, 93:62-72.

136. Jaquet M, Rochat I, Moulin J, Cavin C, Bibiloni R: Impact of coffee consumption on the gut microbiota: a human volunteer study. Int J Food Microbiol 2009, 130:117-121.

137. Bereswill S, Muñoz M, Fischer A, Plickert R, Haag LM, Otto B, Kühl AA, Loddenkemper C, Göbel UB, Heimesaat MM: Anti-inflammatory effects of resveratrol, curcumin and simvastatin in acute small intestinal inflammation. PLoS One 2010, 5:e15099.

138. Kim DC, Ku SK, Lee W, Bae JS: Barrier protective activities of curcumin and its derivative. Inflamm Res 2012, 61:437-444

139. Singal A, Tirkey N, Pilkhwal S, Chopra K: Green tea (Camellia sinensis) extract ameliorates endotoxin induced sickness behavior and liver damage in rat. Phytother Res 2006, 20:125-129.

140. Li J, Ye L, Wang X, Liu J, Wang Y, Zhou Y, Ho W: (-)-Epigallocatechin gallate inhibits endotoxin-induced expression of inflammatory cytokines in human cerebral microvascular endothelial cells. J Neuroinflammation 2012, 9:161.

141. Ghanim H, Sia CL, Upadhyay M, Korzeniewski K, Viswanathan P, Abuaysheh S, Mohanty P, Dandona P: Orange juice neutralizes the proinflammatory effect of a high-fat, high-carbohydrate meal and prevents endotoxin increase and Toll-like receptor expression. Am J Clin Nutr 2010, 91:940-949.

142. Lopresti AL, Hood SD, Drummond PD: Multiple antidepressant potential modes of action of curcumin: a review of its anti-inflammatory, monoaminergic, antioxidant, immune-modulating and neuroprotective effects. J Psychopharmacol 2012, 26:1512-1524.

143. Zhu WL, Shi HS, Wei YM, Wang SJ, Sun CY, Ding ZB, Lu L: Green tea polyphenols produce antidepressant-like effects in adult mice. Pharmacol Res 2012, 65:74-80.

144. Kumar B, Arora V, Kuhad A, Chopra K: Vaccinium myrtillus ameliorates unpredictable chronic mild stress induced depression: possible involvement of nitric oxide pathway. Phytother Res 2012, 26:488-497.

145. Mori-Okamoto J, Otawara-Hamamoto $\mathrm{Y}$, Yamato $\mathrm{H}$, Yoshimura $\mathrm{H}$ : Pomegranate extract improves a depressive state and bone properties in menopausal syndrome model ovariectomized mice. J Ethnopharmacol 2004, 92:93-101.
146. Yu Y, Wang R, Chen C, Du X, Ruan L, Sun J, Li J, Zhang L, O'Donnell JM, Pan J, $X u Y$ : Antidepressant-like effect of trans-resveratrol in chronic stress model: Behavioral and neurochemical evidences. Psychiatr Res 2013, 47:315-322.

147. Chepulis LM, Starkey NJ, Waas JR, Molan PC: The effects of long-term honey, sucrose or sugar-free diets on memory and anxiety in rats. Physiol Behav 2009, 97:359-368.

148. Kassim M, Achoui M, Mansor M, Yusoff KM: The inhibitory effects of Gelam honey and its extracts on nitric oxide and prostaglandin $\mathrm{E}(2)$ in inflammatory tissues. Fitoterapia 2010, 81:1196-1201.

149. Ezz El-Arab AM, Girgis SM, Hegazy EM, Abd El-Khalek AB: Effect of dietary honey on intestinal microflora and toxicity of mycotoxins in mice. BMC Complement Altern Med 2006, 6:6.

150. Li S, Zhao Y, Zhang L, Zhang X, Huang L, Li D, Niu C, Yang Z, Wang Q: Antioxidant activity of Lactobacillus plantarum strains isolated from traditional Chinese fermented foods. Food Chem 2012, 135:1914-1919.

151. Ahrne S, Hagslatt ML: Effect of lactobacilli on paracellular permeability in the gut. Nutrients 2011, 3:104-117.

152. Kim KM, Yu KW, Kang DH, Suh HJ: Anti-stress and anti-fatigue effect of fermented rice bran. Phytother Res 2002, 16:700-702

153. Ducrotté $P$, Sawant $P$, Jayanthi $V$ : Clinical trial: Lactobacillus plantarum 299v (DSM 9843) improves symptoms of irritable bowel syndrome. World J Gastroenterol 2012, 18:4012-4018.

154. Karlsson CL, Molin G, Fåk F, Johansson Hagslätt ML, Jakesevic M, Håkansson Å, Jeppsson B, Weström B, Ahrné S: Effects on weight gain and gut microbiota in rats given bacterial supplements and a highenergy-dense diet from fetal life through to 6 months of age. $\mathrm{Br} J$ Nutr 2011, 106:887-895

155. Axling U, Olsson C, Xu J, Fernandez C, Larsson S, Ström K, Ahrné S, Holm C, Molin G, Berger K: Green tea powder and Lactobacillus plantarum affect gut microbiota, lipid metabolism and inflammation in high-fat fed C57BL/6J mice. Nutr Metab 2012, 9:105.

156. Chen H, Hayek S, Rivera Guzman J, Gillitt ND, Ibrahim SA, Jobin C, Sang S: The microbiota is essential for the generation of black tea theaflavinsderived metabolites. PLoS One 2012, 7:e51001.

157. Isik F, Tunali Akbay T, Yarat A, Genc Z, Pisiriciler R, Caliskan-Ak E, Cetinel S, Altıntas A, Sener G: Protective effects of black cumin (Nigella sativa) oil on TNBS-induced experimental colitis in rats. Dig Dis Sci 2011, 56:721-730

158. Islam MT, Selim A, Sayed M, Khatun M, Siddiqui M, Alam M, Hossain M: Nigella sativa L. supplemented diet decreases egg cholesterol content and suppresses harmful intestinal bacteria in laying hens. J Anim Feed Sci 2011, 20:587-598.

159. Hosseini M, Zakeri S, Khoshdast S, Yousefian FT, Rastegar M, Vafaee F, Kahdouee S, Ghorbani F, Rakhshandeh H, Kazemi SA: The effects of Nigella sativa hydro-alcoholic extract and thymoquinone on lipopolysaccharide induced depression like behavior in rats. J Pharm Bioallied Sci 2012, 4:219-225.

160. Zhang H, Wang J, Menghebilige M, Chen Y, Yun Y, Sun T, Li H, Guo M Nutritive composition of Tarag, the traditional naturally-fermented goat milk in China. Ecol Food Nutr. 2009, 48:112-122.

161. Rahman MM, Kim WS, Ito T, Kumura H, Shimazaki K: Growth promotion and cell binding ability of bovine lactoferrin to Bifidobacterium longum. Anaerobe 2009, 15:133-137.

162. Drago-Serrano ME, de la Garza-Amaya M, Luna JS, Campos-Rodríguez R: Lactoferrin-lipopolysaccharide (LPS) binding as key to antibacterial and antiendotoxic effects. Int Immunopharmacol 2012, 12:1-9.

163. Maga EA, Desai PT, Weimer BC, Dao N, Kültz D, Murray JD: Consumption of lysozyme-rich milk can alter microbial fecal populations. Appl Environ Microbiol 2012, 78:6153-6160

164. Marchbank T, Davison G, Oakes JR, Ghatei MA, Patterson M, Moyer MP, Playford RJ: The nutriceutical bovine colostrum truncates the increase in gut permeability caused by heavy exercise in athletes. Am J Physiol Gastrointest Liver Physiol 2011, 300:G477-G484.

165. Yary T, Aazami S, Soleimannejad K: Dietary intake of magnesium may modulate depression. Biol Trace Elem Res 2013, 151:324-329.

166. Pachikian BD, Neyrinck AM, Deldicque L, De Backer FC, Catry E, Dewulf EM, Sohet FM, Bindels LB, Everard A, Francaux M, Guiot Y, Cani PD, Delzenne NM: Changes in intestinal bifidobacteria levels are associated with the inflammatory response in magnesium-deficient mice. J Nutr 2010, 140:509-514. 
167. Młyniec K, Davies CL, Budziszewska B, Opoka W, Reczyński W, Sowa-Kućma M, Doboszewska U, Pilc A, Nowak G: Time course of zinc deprivation-induced alterations of mice behavior in the forced swim test. Pharmacol Rep 2012, 64:567-575.

168. Zhong W, McClain CJ, Cave M, Kang YJ, Zhou Z: The role of zinc deficiency in alcohol-induced intestinal barrier dysfunction. Am J Physiol Gastrointest Liver Physiol 2010, 298:G625-G633.

169. Malo MS, Alam SN, Mostafa G, Zeller SJ, Johnson PV, Mohammad N, Chen KT, Moss AK, Ramasamy S, Faruqui A, Hodin S, Malo PS, Ebrahimi F, Biswas B, Narisawa S, Millán JL, Warren HS, Kaplan JB, Kitts CL, Hohmann EL, Hodin RA: Intestinal alkaline phosphatase preserves the normal homeostasis of gut microbiota. Gut 2010, 59:1476-1484.

170. Kawai Y, Ishii T, Morotomi M, Mutai M: Depression of activity of intestinal mucosal alkaline phosphatase with gastrointestinal microorganisms. Appl Environ Microbiol 1978, 36:381-383.

171. Zhao Y, Qin G, Sun Z, Che D, Bao N, Zhang X: Effects of soybean agglutinin on intestinal barrier permeability and tight junction protein expression in weaned piglets. Int J Mol Sci 2011, 12:8502-8512.

172. Ying C, Chunmin Y, Qingsen L, Mingzhou G, Yunsheng Y, Gaoping M, Ping W: Effects of simulated weightlessness on tight junction protein occludin and Zonula Occluden-1 expression levels in the intestinal mucosa of rats. Huazhong Univ Sci Technolog Med Sci 2011, 31:26-32.

173. Hanstock TL, Mallet PE, Clayton EH: Increased plasma d-lactic acid associated with impaired memory in rats. Physiol Behav 2010, 101:653-659.

174. Hanstock TL, Clayton EH, Li KM, Mallet PE: Anxiety and aggression associated with the fermentation of carbohydrates in the hindgut of rats. Physiol Behav 2004, 82:357-368.

175. Hanstock TL, Claytons EH, Mallet PE: Anxiety following increased hind-gut fermentation. Asia Pac J Clin Nutr 2003, 12(Suppl):S12.

176. Zhong SS, Song JX, Zhang ZS, Li SM, Wang L: The protective effects of bifidobacterial adhesin on ischemic reperfusion injury of intestine in rats. Zhonghua Nei Ke Za Zhi 2011, 50:863-867.

177. Tashiro Y, Kaneko W, Sun Y, Shibata K, Inokuma K, Zendo T, Sonomoto K: Continuous D-lactic acid production by a novel thermotolerant Lactobacillus delbrueckii subsp. lactis QU 41. Appl Microbiol Biotechnol 2011, 89:1741-1750.

178. Ben-Yahia L, Mayeur C, Rul F, Thomas M: Growth advantage of Streptococcus thermophilus over Lactobacillus bulgaricus in vitro and in the gastrointestinal tract of gnotobiotic rats. Benef Microbes 2012, 3:211-219.

179. Schepens MA, Rijnierse A, Schonewille AJ, Vink C, Brummer RJ, Willemsen LE, van der Meer R, Bovee-Oudenhoven IM: Dietary calcium decreases but shortchain fructo-oligosaccharides increase colonic permeability in rats. $\mathrm{Br} J \mathrm{Nutr}$ 2010, 104:1780-1786.

180. Ewaschuk JB, Johnson IR, Madsen KL, Vasanthan T, Ball R, Field CJ: Barleyderived $\beta$-glucans increases gut permeability, ex vivo epithelial cell binding to $\mathrm{E}$. coli, and naive T-cell proportions in weanling pigs. J Anim Sci 2012, 90:2652-2662.

181. Thomas RH, Meeking MM, Mepham JR, Tichenoff L, Possmayer F, Liu S, MacFabe DF: The enteric bacterial metabolite propionic acid alters brain and plasma phospholipid molecular species: further development of a rodent model of autism spectrum disorders. J Neuroinflammation 2012, 9:153.

182. Editors: Life without bacteria. JAMA 1912, 58:1603-1604.

183. Diaz Heijtz R, Wang S, Anuar F, Qian Y, Björkholm B, Samuelsson A, Hibberd ML, Forssberg $\mathrm{H}$, Pettersson S: Normal gut microbiota modulates brain development and behavior. Proc Natl Acad Sci USA 2011, 108:3047-3052.

184. Neufeld KA, Kang N, Bienenstock J, Foster JA: Effects of intestinal microbiota on anxiety-like behavior. Commun Integr Biol 2011, 4:492-494.

185. Neufeld KM, Kang N, Bienenstock J, Foster JA: Reduced anxiety-like behavior and central neurochemical change in germ-free mice. Neurogastroenterol Motil 2011, 23:255-264

186. Sudo N, Chida Y, Aiba Y, Sonoda J, Oyama N, Yu XN, Kubo C, Koga Y: Postnatal microbial colonization programs the hypothalamic-pituitary-adrenal system for stress response in mice. J Physiol 2004, 558(Pt 1):263-275.

187. Gareau MG, Wine E, Rodrigues DM, Cho JH, Whary MT, Philpott DJ, Macqueen G, Sherman PM: Bacterial infection causes stress-induced memory dysfunction in mice. Gut 2011, 60:307-317.

188. Benson A, Pifer R, Behrendt CL, Hooper LV, Yarovinsky F: Gut commensal bacteria direct a protective immune response against Toxoplasma gondii. Cell Host Microbe 2009, 6:187-196.
189. Ennaceur A, Michalikova S, van Rensburg R, Chazot PL: Are benzodiazepines really anxiolytic? Evidence from a 3D maze spatial navigation task. Behav Brain Res 2008, 188:136-153.

190. Pedersen MG, Mortensen PB, Norgaard-Pedersen B, Postolache TT: Toxoplasma gondii infection and self-directed violence in mothers. Arch Gen Psychiatry 2012, 69:1123-1130.

191. Henriquez SA, Brett R, Alexander J, Pratt J, Roberts CW: Neuropsychiatric disease and Toxoplasma gondii infection. Neuroimmunomodulation 2009, 16:122-133.

192. De Martino B, Camerer CF, Adolphs R: Amygdala damage eliminates monetary loss aversion. Proc Natl Acad Sci USA 2010, 107:3788-3792.

193. Butler RK, Sharko AC, Oliver EM, Brito-Vargas P, Kaigler KF, Fadel JR, Wilson MA: Activation of phenotypically-distinct neuronal subpopulations of the rat amygdala following exposure to predator odor. Neuroscience 2011, 175:133-144.

194. Putman P, Antypa N, Crysovergi P, van der Does WA: Exogenous cortisol acutely influences motivated decision making in healthy young men. Psychopharmacology (Berl) 2010, 208:257-263.

195. Du Y, Yang M, Lee S, Behrendt CL, Hooper LV, Saghatelian A, Wan Y. Maternal western diet causes inflammatory milk and TLR2/4-dependent neonatal toxicity. Genes Dev 2012, 26:1306-1311.

196. Hooper LV, Wong MH, Thelin A, Hansson L, Falk PG, Gordon Jl: Molecular analysis of commensal host-microbial relationships in the intestine. Science 2001, 291:881-884.

197. Desbonnet L, Garrett L, Clarke G, Bienenstock J, Dinan TG: The probiotic Bifidobacteria infantis: An assessment of potential antidepressant properties in the rat. J Psychiatr Res 2008, 43:164-174.

198. Ho JJ: Appropriate use of antibiotics in the NICU. East J Med 2010, 15:133-138.

199. Nosarti C, Reichenberg A, Murray RM, Cnattingius S, Lambe MP, Yin L, MacCabe J, Rifkin L, Hultman CM: Preterm birth and psychiatric disorders in young adult life. Arch Gen Psychiatry 2012, 69:E1-E8.

200. Khandaker GM, Zimbron J, Lewis G, Jones PB: Prenatal maternal infection, neurodevelopment and adult schizophrenia: a systematic review of population-based studies. Psychol Med 2013, 43:239-257.

201. Xu X, Hong X, Xie L, Li T, Yang Y, Zhang Q, Zhang G, Liu X: Gestational and lactational exposure to bisphenol-A affects anxiety- and depression-like behaviors in mice. Horm Behav 2012, 62:480-490.

202. Merrifield CA, Lewis MC, Claus SP, Pearce JT, Cloarec O, Duncker S, Heinzmann SS, Dumas ME, Kochhar S, Rezzi S, Mercenier A, Nicholson JK, Bailey M, Holmes E: Weaning diet induces sustained metabolic phenotype shift in the pig and influences host response to Bifidobacterium lactis NCC2818. Gut 2012. doi:10.1136/gutjnl-2011-301656.

doi:10.1186/1757-4749-5-3

Cite this article as: Bested et al.: Intestinal microbiota, probiotics and mental health: from Metchnikoff to modern advances: Part II contemporary contextual research. Gut Pathogens 2013 5:3.

\section{Submit your next manuscript to BioMed Central and take full advantage of:}

- Convenient online submission

- Thorough peer review

- No space constraints or color figure charges

- Immediate publication on acceptance

- Inclusion in PubMed, CAS, Scopus and Google Scholar

- Research which is freely available for redistribution 